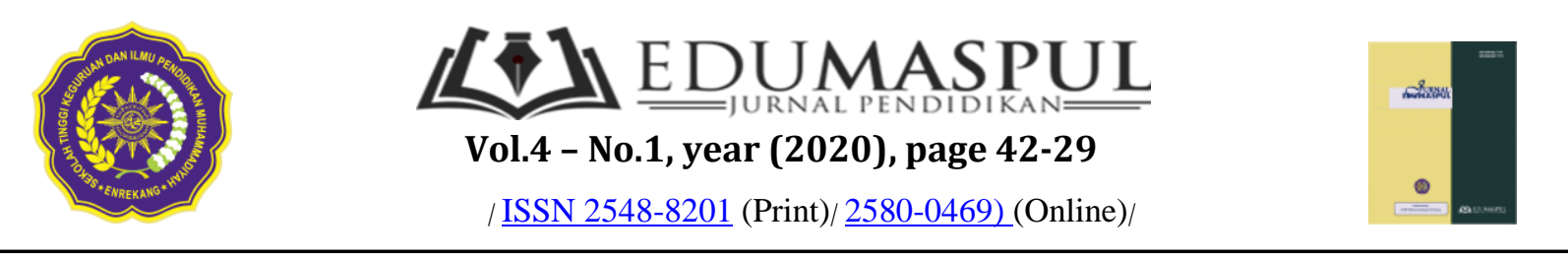

\title{
Pengaruh Penggunaan Media Audio Visual Terhadap Motivasi dan Hasil Belajar IPA Siswa Kelas V SD Negeri Bontoramba
}

\author{
Dian Angreiny ${ }^{1}$,Muhiddin Muhiddin ${ }^{2}$, Nurlina Nurlina ${ }^{3}$ \\ 1,2,3 (Magister Pendidikan Dasar, Universitas Muhammadiyah Makassar, Indonesia). \\ * Corresponding Author. E-mail: ${ }^{1}$ angreinydian1@gmail.com
}

\begin{abstract}
Abstrak
Penelitian ini dilatar belakangi oleh rendahnya motivasi dan hasil belajar peserta didik yang salah satu faktornya adalah penggunaan dan pemilihan media pembelajaran yang kurang sesuai. Sehingga peneliti melakukan eksperimen pembelajaran dengan menggunakan media pembelajaran audio visual. Rumusan masalah dalam penelitian ini "Apakah ada pengaruh penggunaan media audio visual terhadap motivasi dan hasil belajar siswa kelas V SD Negeri Bontoramba Pallangga?. Adapun tujuan penelitian ini untuk mengetahui pengaruh penggunaan media audio visual terhadap motivasi dan hasil belajar siswa kelas V SD Negeri Bontoramba, Pallangga. Pendekatan penelitian yang digunakan adalah kuantitatif dengan jenis penelitian eksperimen semu. Teknik sampling menggunakan purposive sampling. Populasi dalam penelitian ini adalah seluruh siswa kelas V SD dari delapan Sekolah Dasar Negeri yang terdapat dalam gugus VI Kecamatan Pallangga, Kabupaten Gowa, sampel yang diambil adalah peserta didik kelas V-A dan V-B SD Negeri Bontoramba. Teknik pengumpulan data menggunakan metode angket,dan tes. Teknik analisis data yang digunakan adalah Uji Manova, yang sebelumnya diuji prasyarat yaitu normalitas dan homogenitas. Hasil penelitian ini menunjukkan Hasil uji manova angket motivasi dan post test diperoleh nilai Sig. sebesar 0,003. 0,003 0,05 maka $\mathrm{Ho}$ ditolak dan $\mathrm{Ha}$ diterima, artinya ada pengaruh media audio visual terhadap motivasi dan hasil belajar peserta didik SD Negeri Bontoramba. Jadi, dapat disimpulkan bahwa pada penelitian ini media audio visual memiliki pengaruh terhadap motivasi dan hasil belajar peserta didik.
\end{abstract}

Kata Kunci: Media Audio Visual, Motivasi Belajar, Hasil Belajar.

\begin{abstract}
This study is based on low motivation and learning outcomes learners because one of all factor is using and election the media less appropriate learning. So the researchers conducted experimental learning by using audio visual learning media. Formulation of problem in this research are Is there any effect of using audio visual media on motivation and learning outcomes of 5 th grade students at Bontoramba pallangga primary school? The purpose of this study is To explain effect of using audio visual media on motivation and learning outcomes of 5 th grade students at Bontoramba pallangga primary school. The research approach used is quantitative with the kind of quasi-experiment research. The sampling technique uses purposive sampling. The study population was all students of class $V$ in Pallangga, sample taken are students of class $V-A$ and $V-B$ SD Negeri Bontoramba, Pallangga. Technique of collecting data using questionnaires, and tests. Data analysis techniques used is the Manova Test, which previously tested the prerequisite of normality and homogenity. The results showed that Manova test results questionnaire motivation and post test obtained Sig value. of $0.000 .0 .000<0.05$ then rejected and accepted, meaning there is effect of using audio visual media on motivation and learning outcomes of 5 th grade students at bontoramba pallangga primary
\end{abstract}


school. So, it can be concluded that research audio visual media have the influence to motivation and learning outcomes of students.

Keywords: Audio Visual Media, Learning Motivation, Learning Outcomes.

\section{Pendahuluan}

Belajar adalah suatu proses yang kompleks yang terjadi pada diri setiap orang sepanjang hidupnya. Proses belajar itu terjadi karna adanya interaksi antara seseorang dengan lingkungannya. Oleh karena itu belajar bisa terjadi kapan saja dan dimana saja. Salah satu pertanda bahwa seseorang itu telah belajar adalah adanya perubahan tingkah laku pada diri orang itu yang mungkin disebabkan oleh terjadinya perubahan pada tingkat pengetahuan, ketarampilan atau sikapnya (Arsyad 2013:1). Belajar adalah proses yang terjadi pada seseorang dari tidak tahu menjadi tahu. Seseorang dianggap sudah mengalami proses belajar jika sudah mengalami perubahan.

Berdasarkan hasil observasi awal terungkap bahwa penggunaan media di sekolah SD Negeri Bontoramba masih sangat sederhana, hanya menggunakan gambar yang terdapat pada buku paket. Dampak yang terjadi membuat siswa menjadi bosan, dan kurang bersemangat sehingga menjadi kurang tertarik pada pembelajaran.

Hasil wawancara dengan guru juga terungkap bahwa untuk mata pelajaran IPA, Nilai Kriteria Ketuntasan Minimal (KKM) yang ditentukan oleh guru adalah 70, dan dari hasil belajar dua rombel kelas $V$, sebanyak $68,97 \%$ siswa tidak mencapai target KKM. Penggunaan media gambar yang terlalu sering membuat siswa kurang tertarik sehingga, pada pembelajaran IPA cocok menggunakan media audio visual karena dapat mempermudah siswa belajar dalam upaya memahami materi pembelajaran sehingga, diharapkan siswa dapat mencapai target KKM.
Menyikapi hal tersebut peneliti menawarkan sebuah media, yakni Media Audio-Visual dengan harapan dapat membantu guru dan siswa dalam meningkatkan motivasi dan hasil belajar siswa khususnya IPA.

Tawaran tersebut diperkuat dengan beberapa kajian teori yang menjelaskan, bahwa dengan menggunakan media audiovisual, siswa akan termotivasi dan proses pembelajaran akan lebih menarik bagi siswa. Beberapa hal yang mendukung pernyataan tersebut sebagai berikut:

Dalam penelitian Zaini menegaskan bahwa pembelajaran akan lebih menarik dan membantu siswa dalam memahami apa yang sedang dipelajari jika guru menggunakan media pembelajaran disamping menggunakan metode yang bervariasi (Zaini 2008:14). Karena dalam proses pembelajaran, banyak tujuan yang harus dicapai, salah satunya adalah tujuan intruksional, yakni tujuan khusus yang mencakup kemampuan yang harus dimiliki oleh anak didik setelah mempelajari satu bahasan tertentu dalam satu kali pertemuan yang harus disesuaikan dengan kompetensi yang telah ditentukan (Sanjaya 2009:8).

Dari uraian latar belakang diatas, maka rumusan masalah dalam penelitian ini adalah "Apakah penggunaan media Audio-Visual berpengaruh terhadap motivasi dan hasil belajar IPA siswa kelas $\mathrm{V}$ di SD Negeri Bontoramba Pallangga?.

Tujuan dari penelitian ini adalah untuk mengetahui "Pengaruh Penggunaan Media Audio-Visual terhadap motivasi dan hasil belajar IPA siswa kelas $V$ di SD Negeri Bontoramba Pallangga".

Manfaat penelitian ini dapat menambah khazanah ilmu tentang penggunaan media, motivasi, dan prestasi 
belajar siswa khususnya mata pelajaran Ilmu Pengetahuan Alam.

\section{Metode}

Jenis penelitian ini adalah Penelitian kuantitatif Quasi Eksperimen dengan desain penelitian Control-Group Pretestposttest Design ( Sugiyono, 2013:11).

Tabel 1. Control-Group Pretest-posttest Design

\begin{tabular}{|c|c|l|c|}
\hline Group & Pretest & Perlakuan & Posttest \\
\hline KE & K-1 & $\begin{array}{c}\text { Media audio } \\
\text { visual }\end{array}$ & K -2 \\
\hline KK & K - 2 & - & K -2 \\
\hline
\end{tabular}

Penelitian ini dilakukan di SD Negeri Bontoramba dengan mengambil sampel siswa kelas Va sebagai kelas eksperimen dan kelas Vb sebagai kelas kontrol.

Teknik pengumpulan data dalam penelitian ini adalah menggunakan teknik angket, dan tes.

Teknik analisis data dilakukan dengan cara yaitu:

1. Validasi Instrumen ahli (expert judgement)

Validasi ini di uji menggunakan uji Gregory dengan rumus :

$$
\text { Validasi Isi }=\frac{D}{A+B+C+D}
$$

Keterangan:

$A=$ Sel yang menunjukkan kedua penilai/pakar menyatakan tidak relevan.

$B \& C \quad=$ Sel yang menunjukkan perbedaan pandangan antar penilaian/pakar.

$\mathrm{D}=$ Sel yang menunjukkan kedua penilai/pakar memenuhi vaidasi isi.
Tabel 2. Kesepakatan Dua Pakar Menurut Model Gregory dalam Ruslan (2009)

\begin{tabular}{|c|c|c|c|}
\hline \multicolumn{2}{|c|}{} & \multicolumn{2}{c|}{ Validator I } \\
\cline { 2 - 4 } \multicolumn{2}{|c|}{$\begin{array}{c}\text { Tabulasi Penilaian } \\
\text { dari ahli }\end{array}$} & $\begin{array}{c}\text { Tidak } \\
\text { Relevan } \\
\text { Skor } \\
\text { (1-2) }\end{array}$ & $\begin{array}{c}\text { Relevan } \\
\text { Skor } \\
\text { (3-4) }\end{array}$ \\
\hline \multirow{4}{*}{ Validator } & $\begin{array}{c}\text { Tidak } \\
\text { Relevan } \\
\text { Skor } \\
\text { (1-2) }\end{array}$ & A & B \\
\cline { 2 - 4 } & $\begin{array}{c}\text { Relevan } \\
\text { Skor } \\
\text { (3-4) }\end{array}$ & C & D \\
\hline
\end{tabular}

\section{Statistik Deskriptif}

a. Motivasi Belajar

Untuk mengukur motivasi belajar siswa, peneliti menggunakan angket dengan Skala Likertdan dianalisis menggunakan rumus:

$N A=\frac{\text { Jumlah skor yang diperoleh }}{\text { Jumlah skor maksimal }} \times 100 \%$

Keterangan:

NA = Nilai Akhir

b. Hasil Belajar

Perhitungan hasil belajar
sebagai berikut (Purwanto,
2009:102):

$N A=\frac{\text { Jumlah skor yang diperoleh }}{\text { Jumlah skor maksimal }} \times 100 \%$

Keterangan:

$\mathrm{NA}=$ Nilai Akhir

Siswa dikatakan Tuntas apabila NA $\geq 70$

\section{Statistik Inferensial}

a. Uji Homogenitas

Uji homogenitas menggunakan teknik Levene test berbantuan program SPSS 20.0 for windows 
dengan taraf signifikan lebih besar dari (0.05).

b. Uji Normalitas

Uji Normalitas ini menggunakan software analisis statistic SPSS 20.0 for windows, dilakukan dengan taraf signifikan $5 \%(0,05)$.

c. Uji Hipotesis

Uji Hipotesis menggunakan uji Manovadibantu program SPSS 20.0 for windows dilakukan taraf signifikan lebih kecil dari $(0,05)$.

\section{Hasil dan Pembahasan}

\section{Hasil}

\section{a) Hasil Validasi Instrumen}

Hasil validitas ahli (Expert Judgement)kemudian dianalisis menggunakan uji Gregory dengan rumus :

$$
\text { Validasi Isi }=\frac{D}{A+B+C+D}
$$

Dari tabel hasil validasi Media Pembelajaran audio visual, angket dan tes diperoleh nilai validitas $=1$. jika hasil dari koefisien validitas isi ini tinggi (V > 0,75) maka dapat dinyatakan bahwa hasil pengukuran adalah valid.

\section{b) Statistik Deskriptif}

\section{Motivasi Belajar}

Tabel.3 Klasifilakasi Motivasi Belajar Siswa

\begin{tabular}{|c|c|c|c|c|}
\hline $\begin{array}{c}\text { Angka } \\
\mathbf{1 0 0}\end{array}$ & Nilai & Klasifikasi & K.E & K.K \\
\hline $80-100$ & $8,0-10,0$ & $\begin{array}{c}\text { Sangat } \\
\text { tinggi }\end{array}$ & 20 & 15 \\
\hline $66-79$ & $6,6-7,9$ & Tinggi & 5 & 9 \\
\hline $56-65$ & $5,6-6,5$ & Sedang & 0 & 0 \\
\hline $40-55$ & $4,0-5,5$ & Rendah & 0 & 0 \\
\hline $30-39$ & $3,0-3,9$ & $\begin{array}{c}\text { Sangat } \\
\text { Rendah }\end{array}$ & 0 & 0 \\
\hline
\end{tabular}

\section{Hasil Belajar Siswa}

Tabel 4. Kategori Hasil Belajar Post-test Kelas Eksperimen dan Kelas Kontrol

\begin{tabular}{|c|c|c|c|c|}
\hline $\begin{array}{c}\text { Nilai } \\
\text { Skala } 0-100\end{array}$ & Predikat & K.E & K.K & Kategori \\
\hline $86-100$ & $A$ & 14 & 2 & \multirow{2}{*}{$\begin{array}{c}\text { Sangat } \\
\text { Baik }\end{array}$} \\
\hline $81-85$ & A- & 8 & 2 & \\
\hline $76-80$ & $\mathrm{~B}+$ & 3 & 1 & \multirow[t]{3}{*}{ Baik } \\
\hline 71-75 & $B$ & 0 & 6 & \\
\hline $60-70$ & B- & 0 & 8 & \\
\hline $61-65$ & $\mathrm{C}+$ & 0 & 5 & \multirow{3}{*}{$\begin{array}{c}\text { Cukup } \\
\text { Baik }\end{array}$} \\
\hline 51-55 & $C$ & 0 & 1 & \\
\hline $45-50$ & $\mathrm{C}-$ & 0 & 0 & \\
\hline $0-45$ & $\mathrm{D}$ & 0 & 0 & $\begin{array}{c}\text { Kurang } \\
\text { Baik }\end{array}$ \\
\hline
\end{tabular}

Berdasarkan tabel hasil perhitungan nilai motivasi belajar dan hasil belajar siswa yang diberikan perlakuan yaitu menggunakan media audio visual dengan siswa yang hanya menggunakan metode ceramah saat pembelajaran terlihat adanya perbedaan hasil nilai yang cukup signifikan. Dimana hasil nilai kelas yang menggunakan media audio visual lebih tinggi dibandingkan kelas yang tidak menggunakan media audio visual.

\section{c) Statistik Inferensial}

Hasil analisa uji manova terhadap motivasi dan hasil belajar peserta didik dapat dilihat pada tabel 4.

Dari tabel output uji Manova Motivasi dan Hasil Belajar Siswa menunjukkan nilai signifikansi sebesar 0,000. 0,000 < 0,05 maka $\mathrm{Ho}$ ditolak dan $\mathrm{Ha}$ diterima. Berdasarkan hal tersebut maka dapat disimpulkan bahwa ada pengaruh yang signifikan dalam penggunaan media audio visual terhadap motivasi dan hasil belajar IPA siswa kelas V SD Negeri Bontoramba Pallangga 
Tabel 5. Output Uji Manova Motivasi dan Hasil Belajar Siswa

\begin{tabular}{|c|c|c|c|c|c|c|}
\hline $\begin{array}{l}\text { Sour } \\
\text { ce }\end{array}$ & $\begin{array}{l}\text { Dependen } \\
\text { t Variable }\end{array}$ & $\begin{array}{l}\text { Type III } \\
\text { Sum of } \\
\text { Squares }\end{array}$ & $\mathrm{df}$ & $\begin{array}{l}\text { Mean } \\
\text { Square }\end{array}$ & $\mathrm{F}$ & Sig. \\
\hline \multirow{2}{*}{$\begin{array}{l}\text { Corr } \\
\text { ecte } \\
\text { d } \\
\text { Mod } \\
\text { el }\end{array}$} & Motivasi & $297.680^{a}$ & 1 & 297.68 & 14.144 & .000 \\
\hline & $\begin{array}{l}\text { Hasil } \\
\text { Belajar }\end{array}$ & $\begin{array}{r}3960.50 \\
0^{b}\end{array}$ & 1 & $\begin{array}{r}3960.5 \\
00\end{array}$ & 97.992 & .000 \\
\hline \multirow{3}{*}{$\begin{array}{l}\text { Inter } \\
\text { cept }\end{array}$} & Motivasi & $\begin{array}{r}335872 . \\
080\end{array}$ & 1 & 335872 & 15958. & .000 \\
\hline & Hasil & 314424. & 1 & 314424 & 7779.5 & مחת \\
\hline & Belajar & 500 & 1 & .500 & 75 & .000 \\
\hline \multirow{2}{*}{ Kelas } & Motivasi & 297.680 & 1 & $\begin{array}{r}297.68 \\
0\end{array}$ & 14.144 & .000 \\
\hline & $\begin{array}{l}\text { Hasil } \\
\text { Belaiar }\end{array}$ & $\begin{array}{r}3960.50 \\
0\end{array}$ & 1 & 3960.5 & 97.992 & .000 \\
\hline \multirow{2}{*}{ Error } & Motivasi & 1010.24 & 48 & 21.047 & & \\
\hline & $\begin{array}{l}\text { Hasil } \\
\text { Belajar }\end{array}$ & $\begin{array}{r}1940.00 \\
0\end{array}$ & 48 & 40.417 & & \\
\hline \multirow{2}{*}{ Total } & Motivasi & $\begin{array}{r}337180 . \\
000\end{array}$ & 50 & & & \\
\hline & $\begin{array}{l}\text { Hasil } \\
\text { Belajar }\end{array}$ & $\begin{array}{r}320325 . \\
000\end{array}$ & 50 & & & \\
\hline $\begin{array}{l}\text { Corr } \\
\text { ecte }\end{array}$ & Motivasi & $\begin{array}{r}1307.92 \\
0\end{array}$ & 49 & & & \\
\hline $\begin{array}{l}\text { d } \\
\text { Total }\end{array}$ & $\begin{array}{l}\text { Hasil } \\
\text { Belajar }\end{array}$ & 5900.500 & 49 & & & \\
\hline
\end{tabular}

\section{Pembahasan}

1. Pengaruh Penggunaan Media Audio Visual Terhadap Motivasi Belajar IPA Siswa Kelas V SD Negeri Bontoramba

Hasil analisis deskriptif menunjukkan bahwa motivasi belajar siswa pada kelas yang diterapkan pembelajaran menggunakan media audio visual lebih tinggi dibandingkan dengan motivasi belajar siswa pada kelas yang tanpa menggunakan media audio visual. Hasil analisis inferensial menunjukkan bahwa ada pengaruh penggunaan media audio visual terhadap motivasi belajar siswa kelas $\mathrm{V}$ SD Negeri Bontoramba Pallangga.

Hal ini berdasarkan hasil tabel nilai motivasi belajar pada kelas yang menggunakan media audio visual dan kelas yang tidak menggunakan media audio visual dimana nilai motivasi tertinggi pada kelas yang menggunakan media audio visual adalah 93 sedangkan kelas yang tidak menggunakan media audio visual hanya 85 . Sementara itu nilai terendah pada kelas yang menggunakan media audio visual adalah 77 sedangkan pada kelas yang tidak menggunakan media audio visual adalah 70 . Selain itu jumlah siswa yang memiliki motivasi sangat tinggi lebih banyak pada kelas yang menggunakan media audio visual jika dibandingkan dengan kelas yang tidak menggunakan media audio visual.

Berdasarkan hasil nilai motivasi belajar siswa tersebut terlihat bahwa adanya perbedaan antara motivasi pada siswa yang diberikan perlakuan yaitu menggunakan media audio visual dengan siswa yang tidak diberi perlakuan saat proses pembelajaran.

Tingginya motivasi belajar siswa yang diberikan treatment (perlakuan) berupa penggunaan media audio visual dibandingkan dengan siswa yang tidak diberikan treatment tersebut merupakan manifestasi kelebihan media audio visual itu sendiri. Sadiman (2012) mengemukakan bahwa salah satu kelebihan penggunaan media video adalah membuka ruang kepada siswa untuk menanggapi atau memberikan umpan balik terhadap tayangan dari media tersebut. Hal inilah yang terjadi di kelas yang diajar menggunakan media audio visual dimana kebanyakan siswa antusias untuk mengemukakan tanggapan atau komentarnya terhadap tayangan media audio visual disaat guru memberikan kesempatan kepada siswa untuk mengemukakan ide atau pendapatnya. Antusiasnya siswa untuk mengemukakan ide atau pendapatnya 
tersebut menjadi tanda tingginya motivasi belajar siswa.

Disamping itu penggunaan media audio visual tentunya membawa ketertarikan tersendiri bagi siswa dalam mengikuti pembelajaran di kelas. $\mathrm{Hal}$ ini sesuai dengan gagasan manfaat media audio visual yang telah dibuktikan oleh para ahli bahwa alatalat audio visual jelas mempunyai nilai yang berharga dalam bidang pendidikan. Dari 4 manfaat salah satu diantaranya adalah dapat mendorong keinginan untuk mengetahui lebih banyak lagi tentang hal-hal yang berkaitan dengan materi yang telah disampaikan oleh guru (Hamzah: 1985). Begitu pula dengan tentang manfaat alat bantu audio visual diantaranya adalah dapat mendorong minat dan meningkatkan keingintahuan intelektual (Suprijanto: 2007).

Media audio visual juga memiliki keunikan tersendiri dibandingkan media pembelajaran lainnya. Media atau alat-alat audiovisual adalah alat-alat "audible" artinya dapat didengar dan alat-alat "visible" artinya dapat dilihat (Hamzah: 2007). Alat-alat audio-visual gunanya untuk membuat cara berkomunikasi menjadi efektif. Media audio-visual merupakan bentuk media pengajaran yang terjangkau, pembelajaran menjadi lebih efektif dan efisien sehingga pada akhirnya siswa menjadi lebih mudah memahami materi yang diajarkan.

Berdasarkan paparan di atas dapat disimpulkan bahwa hasil dari penelitian ini adalah ada pengaruh penggunaan media audio visual terhadap motivasi belajar IPA siswa kelas V SD Negeri Bontoramba.

\section{Pengaruh Penggunaan Media Audio Visual Terhadap Hasil Belajar IPA} Siswa Kelas V SD Negeri Bontoramba
Hasil analisis deskriptif menunjukkan bahwa hasil belajar siswa pada kelas yang diterapkan pembelajaran menggunakan media audio visual lebih tinggi dibandingkan dengan hasil belajar siswa pada kelas yang tanpa menggunakan media audio visual. Hasil analisis inferensial menunjukkan bahwa ada pengaruh penggunaan media audio visual terhadap hasil belajar siswa kelas V SD Negeri Bontoramba Pallangga.

Hal ini berdasarkan tabel nilai hasil belajar post-test terlihat bahwa adanya perbedaan hasil nilai post-test antara kelas yang menggunakan media audio visual dan kelas yang tidak menggunakan media audio visual, dimana hasil post-test kelas yang menggunakan media audio visual lebih tinggi dibandingkan dengan kelas yang tidak menggunakan media audio visual. Begitu pula dengan hasil nilai terendah, kelas yang tidak menggunakan media audio visual lebih rendah 10 angka dibandingkan dengan kelas yang menggunakan media audio visual.

Media audio visual dapat mempermudah orang yang menyampaikan dan memudahkan dalam menerima suatu pelajaran atau informasi serta dapat menghindarkan salah pengertian. Selain itu siswa juga dapat belajar dan maju sesuai dengan kecepatan masing-masing. Materi pelajaran dapat dirancang sedemikian rupa sehingga mampu memenuhi kebutuhan siswa, baik yang cepat maupun yang lambat membaca dan memahami.

\section{Simpulan}

Berdasarkan hasil penelitian tentang pengaruh penggunaan media audio visual terhadap motivasi dan hasil belajar siswa kelas $\mathrm{V}$ SD Negeri Bontoramba Pallangga, maka dapat ditarik kesimpulan bahwa terdapat pengaruh penggunaan media audio visual terhadap motivasi dan hasil belajar siswa kelas V SD Negeri Bontoramba Pallangga. 
Hal ini berdasarkan perhitungan uji Manova, untuk motivasi dan hasil belajar diperoleh nilai Sig. sebesar 0,000. 0,000 < 0,05 maka $\mathrm{Ho}$ ditolak dan $\mathrm{Ha}$ diterima. Berdasarkan hal tersebut maka dapat disimpulkan bahwa ada pengaruh yang signifikan media audio visual terhadap motivasi dan hasil belajar siswa kelas V SD Negeri Bontoramba Pallangga.

\section{Daftar Pustaka}

[1] Arsyad Azhar, 2013, Media Pembelajaran, Jakarta: PT. Raja Grafindo Persada

[2] Arsyad Azhar, 2010, Media Pembelajaran, Jakarta: PT. Raja Grafindo Persada

[3] Asnawir, dkk, 2002, Media Pembelajaran, Jakarta: Ciputat Pers

[4] Asri, Budiningsih. 2010, Belajar dan Pembelajaran. Jakarta: Rineka Cipta,

[5] Asyhar Rayandra, 2011, Kreatif Mengembangkan Media Pembelajaran, Jakarta: Gaung Persada Press

[6] Degeng Sudana Nyoman I, 2008, Ilmu Pengajaran Taksonomi Variabel, Jakarta: Depdikbud irjen Perguruan Tinggi Proyek Pengembangan Lembaga Pendidikan Tenaga Kependidikan.

[7] Esti Wuryani Sri, 2004, Psikologi Pendidikan Jakarta: Grasindo

[8] Eko Sujianto Agus, 2009, Aplikasi Statistik dengan SPSS 16.0, Jakarta: PT Prestasi Pustakarya.

[9] Fadillah Muhammad, 2012, Desain Pembelajaran Paud, Jogjakarta : ARUZZ MEDIA

[10] Hasnida, 2014, Media Pembelajaran Kreatif, Jakarta: Luxima.

[11] Hamzah Amir, 1985, Media Audio Visual, Jakarta: Gramedia

[12] lis Kurniawati, Pengaruh Pembelajaran IPA Model Pola Pemberdayaan Berpikir Melalui
Pertanyaan (PBMP) dalam Pembelajaran Kooperatif Team Game Tournament (TGT) Terhadap Motivasi dan Hasil Belajar Siswa Kelas IV MI Darul Ulum Gondang Legi Malang, 2015.

[13] Iskandar, 2012, Perkembangan Anak.Jilid1 Edisi 11. Erlangga: Jakarta

[14] J. Supranto.. Metode Ramalan Kuantitatif Untuk Perencanaan: edisi kedua Jakarta: PT. Gramedia

[15] Ketentuan KKM SD Negeri Bontoramba

[16] Komalari Kokom, 2011, Pembelajaran Kontekstual "Konsep dan Aplikasi" Bandung: Refika Aditama

[17] Maleong Lexy, 2006, Metodologi Penelitian Kualitatif, Bandung: PT Remaja Rosdakarya

[18] Maleong Lexy, J.. 2005, Metodologi Penelitian Kualitatiif Bandung: PT Remaja Rosda Karya.

[19] Mujiono dan Dimyati, 2006, Belajar dan Pembelajaran Jakarta: Rineka Cipta.

[20] Munadi Yudhi, 2010, Media Pembelajaran "Sebuah Pendekatan Baru" Jakarta: Gaung Persada Press

[21] Mudlofir Ali dan Rusydiyah Fatimatur Evi,2015, Desain Pembelajaran Inovatif, Jakarta: PT RajaGrafindo Persada.

[22] Nashar, H, 2004, Peranan Motivasi dan Kemampauan Awal dalam Kegiatan Pembelajaran Jakarta: Delia Press

[23] Nasution, 2003, Metode Research: Penelitiah Ilmiah Jakarta: Bumi Aksara

[24] Nasution, 2007, Metode Research: Penelitiah Ilmiah Jakarta: Bumi Aksara

[25] Nasution, 2010, Berbagai Pendekaan dalam Proses Belajar \& Mengajar. Jakarta: Bumi Aksara 
[26] Purwanto Ngalim, 2009,Psikologi Pendidikan, (Bandung : Remaja RosdaKarya)

[27] Puskur, 2007. Mata Pelajaran IPA untuk Sd/MI. (http: //www.puskur.net /si/sd/ Pengetahuan Alam.pdf.Jakarta: Departemen Pendidikan Nasional, Diakses Tanggal 29 Oktober 2018)

[28] Sagala Syaiful, 2005, Konsep dan Makma Pembelajaran Bandung Alfabeta

[29] Saiful Bahri Djamarah, 2010, Strategi Pembelajaran,Jakarta: Rineka Cipta

[30] Saiful, Bahri Djamarah,. 2002, Psikologi Belajar, Jakarta: Rineka Cipta

[31] Sanjaya Wina, 2009, Strategi Pembelajaran Berorietasi Standar Proses Pendidikan Jakarta: Kencana.

[32] Sanjaya Wina, 2008, Perencanaan dan Desain Sistem Pembelajaran,Jakarta: Kencana.

[33] S.Sadiman Arief, 2008 (Media Pendidikan, Pengertian, Pengembangan, dan Pemanfaatannya) , Jakarta : PT Rajagrafindo Persada

[34] Subiantoro Agung, Pentingnya Praktikum Dalam Pembelajaran IPA. Makalah Pelatihan Pengembangan Praktikum IPA Berbasis Lingkungan, (Jurusan Pendidikan Biologi. Fakultas MIPA. Universitas Negeri Yogyakarta

[35] Sudarmayanti, 2001, Sumber Daya Manusia dan Produktifitas Kerja Jakarta: Bumi Aksara

[36] Sugiyono, 2008, Metode Penelitian Kuantitatif Kualitatif dan R\&D Bandung: Alfabeta
[37]

Trinanto, 2007, Model Pembelajaran Terpadu dalam Teori dan Praktek Jakarta:

[38] Vardiansyah Dani, 2008, Filsafat Ilmu Komunikasi, : suatu Pengantar Indeks Jakarta

[39] Zaini. 2008, Penggunaan Media Pembelajaran untuk Meningkatkan Motivasi siswa dalam kemahiran berbicara bahasa Arab, PTK, UIN Malang

[40] Zainuddin, 1979, Manajemen dan Motivasi, Jakarta: Balai Aksara

\section{Profil Penulis}

Dian Angreiny, Lahir di Makassar, Sulawesi Selatan pada tanggal 10 Maret 1984, anak ketiga dari enam bersaudara pasangan Zainuddin Wahab dan Pudji Astuti Slamet. Penulis telah menikah dengan Hamka Londro, A.Md. Penulis mulai menempuh pendidikan Sekolah Dasar ( 1990-1996), Sekolah Menengah Pertama ( 1996-1999), Sekolah Menengah Atas ( 1999-2002) pada tahun 2002 pada jurusan D2 PGSD Universitas Negeri Makassar sampai tahun 2004 dan melanjutkan jenjang pada jurusan PGSD S1 pada Universitas Muhammadiyah Makassar pada tahun 2010 sampai 2013. Pada tahun 2017 penulis melanjutkan pendidikan di jenjang (S2) dengan memilih Program Studi Pendidikan Dasar pada Program Pascasarjana Universitas Muhammadiyah Makassar. Penulis mengabdi di SD Negeri Bontoramba Kecamatan Pallangga Kabupaten Gowa mulai tahun 2009, untuk memperoleh gelar Magister Pendidikan (M.Pd.), ia menulis dengan judul Pengaruh Penggunaan Media Audio Visual Terhadap Motivasi dan Hasil Belajar Siswa Kelas V SD Negeri Bontoramba Pallangga. 